\title{
The effect of business sphere on competitive advantage and business performance of SMEs
}

\author{
Achmad Daengs GS ${ }^{a^{*}}$, Nuning Kurniasih ${ }^{b}$, Andi Reni ${ }^{c}$, Enny Istanti $^{\text {, }}$, Diana Zuhroh ${ }^{\mathrm{a}}$, and Nur \\ Qomariah $^{\mathrm{e}}$
}

${ }^{a}$ Universitas 45 Surabaya, Indonesia

${ }^{b}$ Faculty of Communication Science, Library and Information Program, Universitas Padjajaran, Indonesia

${ }^{c}$ Universitas Hasanuddin Makassar, Indonesia

${ }^{d}$ Universitas Bhayangkara Surabaya, Indonesia

eSTIE Walisongo Gempol Pasuruan, Indonesia

\section{H R O N I C L E}

Article history:

Received: March 14, 2019

Received in revised format: April

192019

Accepted: April 29, 2019

Available online:

April 30, 2019

Keywords:

SMEs empowerment

Business setting

Competitive advantage

Business performance

Local economic development

\section{A B S T R A C T}

Nowadays, Small and medium enterprises (SMEs) play essential role for the development of the economy. Thus, any improvement on the performance of such organizations may contribute significantly on overall economy. The purpose of this paper is to analyze the effect of business sphere on competitive advantage and business performance. In addition we study the effects of the competitive advantage on business performance of SMEs through a quantitative approach and by considering 50 businessman SMEs built by Surabaya Trade Service Department. Data collection in this study was prepared by distributing questionnaires. Data analysis technique used in this research is SEM analysis with PLS. The results indicate that: (1) business sphere influences on business performance of SMEs under the Surabaya Trade Service Department; (2) business sphere has substantial influence on competitive advantage of SMEs in the Surabaya Trade Service Department; (3) competitive advantage sphere has substantial influence to business performance of SMEs built by Surabaya Trade Service Department.

\section{Introduction}

Small and Medium Enterprises (SMEs) play crucial role for economic growth and reducing unemployment rate (Widarti, 2007). SME is one of the critical parts of the economy in any country such as Indonesia. Facts show that the employment opportunities created by the SME group is far more than the labors that can be absorbed by big enterprises. Therefore, SMEs are anticipated to continue their efforts to deal with increasing unemployment rate. With a lot of absorbing labor means SMEs also have a strategic function in efforts to help the government fight poverty (Tambunan, 2009). Contribution of this group is very consequential on the national economy. SMEs as a one of the key pillars of national economy that have self-sufficient insight has great potential to improve the community welfare.

In Indonesia, the SME sector has faced with many economic crisis for the past few years (Sriyana, 2010). Based on data of the State Ministry of Cooperatives and SMEs 2011-2013, the SMEs has been uprising

* Corresponding author.

E-mail address: bumigora80@gmail.com (A. Daengs GS) 
to $2.41 \%$ from $55,206,444$ business units in 2011 to $56,534,592$ business units in 2012 or $99 \%$ of business people in Indonesia. During the period 2011-2012, the number of SMEs Gross Domestic Bruto has been increased $12.67 \%$ from IDR 4,321,830 billion (2011) to IDR 4.869.568 billion (2012). While the Indonesia Chamber of Commerce and Industry (Kadin) estimates SME sector will rise about $25 \%$ in 2012 compared with 2011's forecast of 15-20\%. By 2013, SMEs was increased. SME development also occurred in Surabaya, which is seen in the SME's number from year to year experiencing rapid growth. Based on the data of Surabaya Cooperatives and Micro Enterprises Office, the number of SMEs reached to more than 4800 businesses.

Thus the existence of SMEs plays an essential and strategic role on the national economic development, which provides an opportunity for the community to dare to open production activities in order to achieve better welfare and living standards through the workforce absorption. On the other hand, SMEs continue to face challenges because SME actors react to the sphere factors changes (Setiawan, 2015). Conditions of SMEs are still marginal both in terms of capital and income since SMEs are still facing poor financial strength. The powerless of SMEs in the national economy at the time before monetary crisis, seems to be only cause of the national economy shattered. Conversely, the growing role of SMEs after the monetary crises, has accelerated the national economic recovery process, so until now the Indonesian economy is gradually enhanced. The national economic policy that has not put SMEs in a strong position, will not support the national economic development success once the country joins the world trade organization. Classic limitations facing SMEs are largely about capital and technology so that SMEs are incapable of upgrading their business activities.

According to Tambunan (2009) the SMEs problem are related to internal and external settings. The higher the company's ability to manage the internal settings, the more likely the company tends to be more proactive in seeking the new opportunities. The companies also be more innovative and creative than its counterparts, to respond to changes of external sphere as well and to take risks and have authority to run corporate decisions. The SMEs performance certainly confronts many challenges that come from the external settings According to Wulandari (2009) the external sphere of the company includes all the surroundings and forces that influence strategic options undertaken by the company and determine its competitive situation. The conditions of the external sphere can affect business performance, as found by Stevanus et al. (2016). Similarly, the internal and external settings have major effects on the performance of SMEs. In this case, it is expected that the government can encourage the ability of business actors in applying the right strategy to confront environmental change, one way is to upgrade the competitive advantage of the business actors. Porter (2003) explains that competitive advantage is the heart of performance to meet competition. Competitive advantage is defined as a benefit strategy of companies that collaborate to create more competitive advantages in their markets. Competitive advantage ultimately grows from the value or benefits that can be created by the company for its buyers more than the cost that must be spent by the company to create it. Nowadays the competitive situation is getting tougher, consumers are increasingly critical in deciding to buy any product or service. Competitive advantage will also be able to help enhance performance of SMEs Setyowati (2015). Based on theoretical and empirical literature review, this research is conducted with the objective to analyze the influence of business sphere on competitive advantage and its impact on business performance on SMEs'.

\section{Literature Review}

\subsection{Business Sphere}

Business sphere is associated with circumstances outside the business entity or industry that affect activities of the organization. According to Pearce and Robinson (2008) sphere analysis can be divided into two main components: external sphere and internal sphere.

An internal sphere analysis is a process whereby a strategic planner reviews marketing and distribution of a company, research and development, production and operations, resources and company employees, as well as financial and accounting factors to determine where firms have substantial capabilities so that 
firms take advantage of opportunities in the most effective and able to deal with threats within the Sphere (Glueck \& Jauch, 2009). According to Pearce and Robinson (2008), the internal Sphere can be measured through several indicators consisting of:
a. Marketing
b. Production
c. Human Resources
d. Finance

According to Coulthard in Wulandari (2009), the external Sphere can be defined as anything to do with consumers, suppliers, and alliances and their influences in improving supply chain effectiveness, while Pearce and Robinson (2008) explain that the company's external Sphere are all circumstances and forces that influence the strategic options (options) undertaken by the company and determine its competitive situation. The strategic management model divides the external sphere into three interacting segments; namely operational setting, industrial setting, and distant setting. According to Pearce and Robinson (2008), the external sphere can be measured through some indicators consisting of:
a. Market
b. Regulation
c. Economics
d. Technology

\subsection{Competitive Advantages}

Competitive advantage is the advantage of competitors obtained by offering lower value and by providing greater benefits because the price is higher (Kotler \& Armstrong, 2012). Further Porter defines competitive advantage as the heart of the company's performance in a competitive market, but after decades of great expansion and ability it has led many companies to lose sight of competitive advantage in strive for further expansion to pursuit diversification (Porter, 2003). Porter (2003) argues competitive advantage is the result of a value creation implementation not a result of simultaneous implementation of existing or current potential competitors, nor through superior execution or implementation same strategy with counterpart.

The competitive advantage in this study is measured through several indicators that refer to Bruque, et. al. (2003), namely:
a. Advantage of price
b. Advantage of innovative products
c. Advantage of customer relationship
d. Advantages of differentiation

\subsection{Business Performance}

According to Helfert (2001), the definition of performance is the outcome of several decisions made continuously by management to achieve certain goals effectively and efficiently, while according to Djarwanto (2000) performance is the level of achievement (work) with tangible results used for achievement a result of several decisions made by management to achieve certain goals effectively and efficiently. Mulia (2002) defines performance as the achievement level (work) of outcome achieved and used to complete the positive outcome. Company performance is the accumulation of end result of all activities and work processes of the company. Performance is a company's full view over a certain period of time, which is the consequence or achievement influenced by the company's operational activities in utilizing the resources (Sampurno, 2010). In measuring performance of the company first we need to understand the meaning of the performance itself. Performance is the company's outcome of operational activities 
by utilizing its resources. According to Sampurno (2010) performance measurement is a periodic determinant of operational effectiveness of an organization and employees based on predetermined targets, standards and criteria. According to Kaihatu et al. (2015) performance measurement is a process to determine how well business activities are implemented to achieve strategic objectives, to eliminate waste and to present timely information to apply continuous improvement. Kaihatu et al. (2015) define performance measurement as a periodic determination of the operational activities of an organization, part of organization and employees based on predetermined targets, standards, and performance.

Performance measurement is a single factor that is critical for any company. Measurements can, among others, be used to assess the company's success (Munawir, 2002). Sampurno (2010) believes the company's performance measurement has different benefits such as: (1) enhance customer satisfaction, (2) impact on corporate reputation, and (3) organizational knowledge or ability. Company performance is important to measure because management needs to understand what factors contribute to high performance of the company or vice versa to know what factors cause the company performance negatively. The performance indicators of SMEs in this study refers to Purwaningsih and Kusuma (2015).

\subsection{Business Characteristics of Small Business}

Tambunan (2009) mentions that after the economic crisis lasts for several years, lessons can be taken that SMEs have better resilience than big business. SMEs with various specifications, particularly small capital, can change the product quickly. Relatively, simple management and the large number of scattered in the territory of Indonesia, causing SMEs have a pretty good resistance to economic turmoil. The meaning of empowerment concept, specifically the concept of SME's empowerment explained that the core of SME empowerment includes 3 things:

a. Enabling business

b. Strengthen the potential or power (empowerment) in order to develop the independence (Ahmar, et. al., 2018).

With the implementation of the agreement on a more open economy between countries, there is a demand for greater efficiency and productivity for SMEs to be able to compete and SME development should continue. Strategic position of SME is already proven to be the focal point when the 1997 monetary crisis hit, but the problems faced by SMEs are also very multifaceted, because characteristics of SMEs are small, labor-intensive, resource-based local with all its limitations. To enhance the SMEs' competitiveness, the chosen development strategy is the one that has the advantage. According to Ahmar (2018), development of SME activities in groups is known as Sentra.

\subsection{Problems Facing Small and Medium Enterprises (SMEs)}

Some things that become SMEs problems in Indonesia are: Marketing aspect, Information Technology, Production and quality of human resources, Access to capital (Anatan, 2008). Similar opinion is stated by Kaihatu, et al. (2015), among others, that although in general SMEs have a good position in national economy, there are still a lot of problems facing the SMEs development such as weakness of access and market share expansion, weakness of access and capital investment, weakness of access to information and technology, weakness in organization and management, weaknesses in business networks and partnerships. All of this is traced from the weakness of human resources (HR) which impact on low quality of products and services resulting in lack of competitiveness, both in local markets, national and international (Kaihatu, et. al, 2015).

\subsection{Local Economic Development}

Development is the expansion effort or realization of potentials, bringing a state of affairs to a more complete state of greater or better, advance something from the earlier to the more recent or simpler to the stage more complex growth (Sugiyono, 2014; Bruque, et. al., 2003). 


\subsection{Conceptual Framework}

Hypothesis

H1 : Business sphere has a significant effect on Business Performance of the SMEs.

$\mathrm{H} 2$ : Business sphere has a significant effect on Competitive Advantage of the SMEs.

H3 : Competitive Advantage has a significant effect on Business Performance of the SMEs

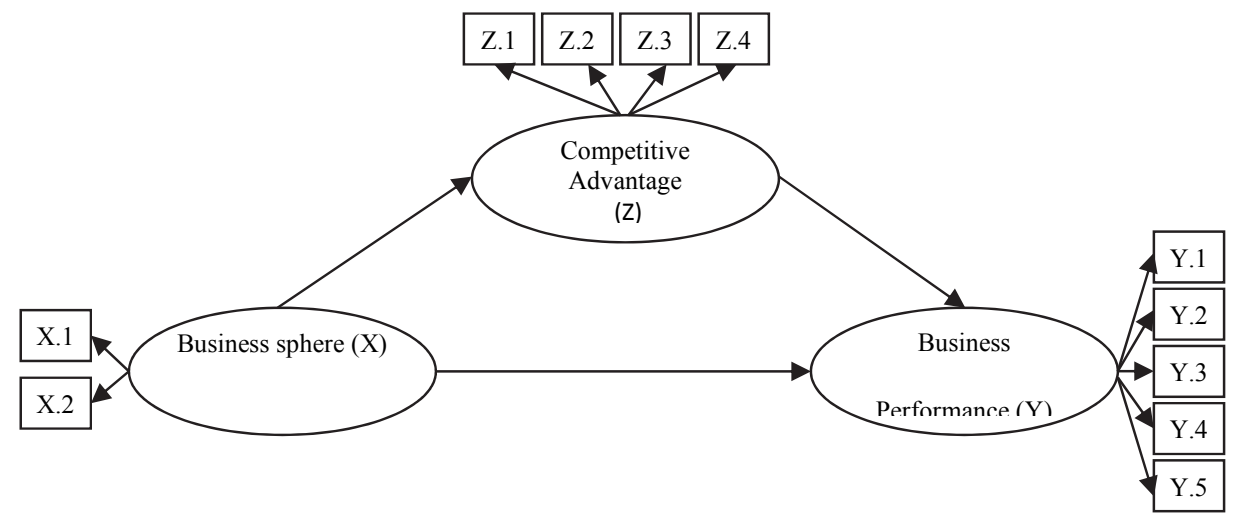

\section{Research Methods}

Fig. 1. Conceptual Framework

The research design of this survey is quantitative data analysis and questionnaire data collection method. This is a causal research because one variable with the other one interrelated variables are the independent and the dependent variables.

\subsection{Population and Sample}

Population in this research includes all SMEs built by Surabaya Trade Service Department. Sample is part of the amount and characteristics possessed by the population (Sugiyono, 2014). Sampling technique is a technique to take sample to determine sample used in the research (Sugiyono, 2014). This study uses the total sampling technique by determining the sample when all members of population used as a sample. So samples used in this study include 50 SMEs actors built by the Surabaya Trade Service Department.

\subsection{Definition of Operational Variables}

\subsubsection{Business sphere (X1)}

Business Sphere variable indicator (Pearce \& Robinson, 2008) include Internal Sphere, External sphere.

\subsubsection{Competitive Advantage (Z)}

The indicator of competitive advantage (Kaihatu, et. al, 2015) are Advantage of Price, Advantage of innovative products, Advantage of customer relationship, Advantages of differentiation.

\subsubsection{Business Performance (Y)}

Indicators of business performance variables are (Purwaningsih \& Kusuma, 2015) Sales Growth, Capital Growth, Workforce Growth, Market Growth, Profit Growth.

\subsection{Data Collection Technique}

According to Sugiyono (2014) questionnaire is a data collection technique conducted by giving a set of written statements to respondents to answer. Scale method used in this survey is Likert. The variables measured on the Likert scale are translated into sub-variables, where the sub-variables are translated into measurable components. 


\subsection{Data Analysis Technique}

According Sugiyono (2014) calculations are performed using Smart Partial Least Square (PLS) tool, due to the multi-path shape and model used in the Reflective form. Calculation model is performed by using Smart PLS tool because of correlation of multi-path, formative and reflective which exist in the dat. The sample in this research includes 50 respondents. Formative model is a model that shows correlation way from indicator to latent variable. The reflective model is a model showing correlation of the latent variable to its indicator.

\section{Analysis and Discussion}

\subsection{Inner Model Test or Structural Model Test}

Finding of this analysis are based on the conformity level and the constructed structural model shows inference that overall model is "relevant" to explain the studied variables and their effects on respective variables. Calculation of Q2 value gained 0,577 or beyond critical limit of 0,5 thus structural model asserted fit and adjusted.

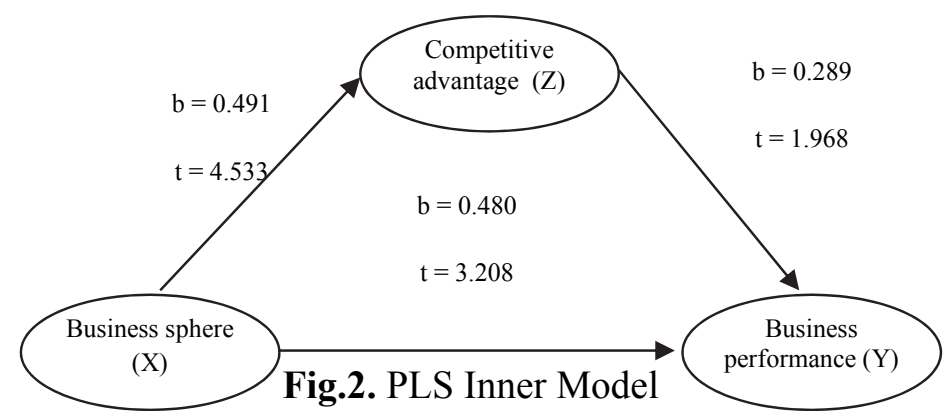

Finding of the inner weight value in Fig. 2 above indicates that Business Performance variables are influenced by Business Sphere and Competitive Advantage, while the Competitive Advantage variables are influenced by Business Sphere shown in the following equation:

$\mathrm{Y}=0.480 \mathrm{X}+0.289 \mathrm{Z}, \mathrm{Z}=0.491 \mathrm{X}$

For Business Sphere variables affecting Competitive Advantage, the $\mathrm{R}^{2}$ value of 0.241 indicates "weak" model. In addition, for Business Sphere variable and Competitive Advantage affecting Business Performance variable, the $\mathrm{R}^{2}$ yields 0.459 indicating the model to be "moderate".

\subsection{Hypothesis Testing Results}

\subsubsection{Hypothesis Test $1\left(H_{l}\right)$}

First hypothesis has been proved to be valid, since the results of the data analysis yields a t-value of 3.208 which is meaningful when the level of significance is five percent, so it can be said that the Business Sphere has a significant effect on Business Performance. The direction of correlation between two variables is positive which means that business Sphere may positively improve business performance.

\subsubsection{Hypothesis $2\left(\mathrm{H}_{2}\right)$}

Second hypothesis has also been confirmed since the results of the data analysis yields a t-value of 4.533 which is meaningful when the level of significance is five percent and it can be said that Business Sphere has a significant effect to Competitive Advantage on SMEs. The direction of the correlation between two variables is positive which means the better the business Sphere, the better the Competitive Advantage on SMEs. 


\subsubsection{Hypothesis $3\left(H_{3}\right)$}

Third hypothesis of this survey has also been approved, since the result of the data analysis yields a tvalue of 1.968 which is meaningful when the level of significance is five persent. Thus, it can be said that Competitive Advantage has a significant effect to Business Performance on SMEs. The direction of the correlation between two variables is positive which means the better the competitive advantage, the better the business performance of SMEs.

\subsection{Discussion}

Various changes occur inside corporate circle, requires businesses to make adjustments in order to win the competition. In addition, changes occur within the corporate circle, demanding that every business person always gives attention and respond to the environment and formulates different strategies to be able to anticipate the changes and achievement of corporate goals (Stevanus et al., 2016). The existing theories about management and organization make the correlation more emphasized and they affect the business sphere to enhance organizational performance. Consequence of the theoretical evidence from this research can be used to solve the problems that occur in the business sphere and organizational performance.

The findings in this study prove that the business sphere plays vital role in increasing the competitive advantage. In other words, competitive advantage in SMEs can be established through management of a good business sphere. Therefore, if the SMEs in charge of the Surabaya Trade Service Department want to increase the competitive advantage it is necessary to pay attention to the business sphere both internally and externally. This result is in line with the findings research conducted by Stevanus et al. (2016) who examined the SMEs in the Malang town where the results verify that the business sphere has a significant effect on competitive advantage.

Findings of this study prove that competitive advantage plays an important role in improving business performance of SMEs. In other words, business performance in SMEs can be established through competitive advantage by SMEs. Porter in Munawir (2002) state that competitive advantage is needed to enhance the performance of small industries. Porter in Munawir (2002) explains that competitive advantage is the heart of performance to face the competition. Competitive advantage is defined as a benefit strategy of companies that collaborate to create more competitive advantages in their markets. The existence of competitive advantage will improve company performance. Competitive advantage principally grows from the value or benefits that can be created by the company for its buyers more than the cost that must be spent by the company to create it. Nowadays competitive advantage is getting tougher, consumers are increasingly critical in deciding to buy any product or service.

Day and Wensley in Bruque et al. (2003) stated that competitive advantage is a form of strategy to assist the company in maintaining its survival. Then Ferdinand's expression in Meutia (2013) explains that in competitive markets, ability of the firms to produce performance depends on the degree of competitive advantage. The upshot of this study are in line with the findings of Munawir (2002) who examined the SMEs in Malang town where the results prove that competitive advantage significantly affect business performance.

\section{Conclusion}

Business Sphere has a significant effect on Business Performance on SMEs assisted by Surabaya Trade Service Department, Business Sphere has a significant effect on the Competitive Advantage on SMEs assisted by the Surabaya Trade Service Department, Competitive Advantage has a significant effect on Business Performance on SMEs assisted by the Surabaya Trade Service Department, It is expected that Small and Medium Enterprises can improve the performance, especially the human resources and marketing sector, especially focus on improving the quality of the more skilled human resources, so that the technical aspects of production can run smoothly and quality, it is expected that Small and Medium Enterprises especially at the Directorate Surabaya Trade Service Department can improve the company 
performance through deep analysis of sphere and combined by formulating the right strategy to achieve competitive advantage.

\section{References}

Ahmar, A. S., Kurniasih, N., Irawan, D. E., Sutiksno, D. U., Napitupulu, D., Setiawan, M. I., ... \& Abraham, J. (2018, January). Lecturers' understanding on indexing databases of SINTA, DOAJ, Google Scholar, SCOPUS, and Web of Science: A study of Indonesians. In Journal of Physics: Conference Series (Vol. 954, No. 1, p. 012026). IOP Publishing.

Anatan, L. (2008). Service Excellence Competing Through Competitiveness. Bandung: Alfabeta.

Bruque-Cámara, S., Fuentes, J. M., Hernández-Ortiz, M. J., \& Vargas-Sánchez, A. (2003). Information Technology and Competitive Advantage: The Role of the Ownership Structure. ECIS 2003 Proceedings, 6.

Djarwanto, P. S., \& Subagyo, P. (2001). Mengenal beberapa uji statistik dalam penelitian. Liberty, Yogyakarta.

Glueck, W.F., \& Jauch, L. R. (2009). Strategy Management and Business Policy. New. York: McGraw-Hill

Helfert, E. A. (2001). Financial Analysis: Tools and Techniques: A Guide for Managers (pp. 221-296). New York: McGraw-Hill.

Kaihatu, Thomas, S., Daeng, G.S., Achmad, \& ATL Indrianto. (2015). Manajemen Komplain. Yogyakarta: Penerbit Andi Yogyakarta.

Kotler, P., \& Armstrong, G. (2012). Principles of Marketing (ed.). New Jersey.

Mulia, T. W. (2002). Analisis Laporan Keuangan. Surabaya: Gama Media.

Munawir, S. (2002). Analisis Laporan Keuangan. Yogyakarta: Liberty.

Pearce, J.A., \& Robinson, R.B. (2008). Manajemen Strategis: Formulasi,. Implementasi, dan Pengendalian. Jakarta: Salemba Empat.

Porter, M.E. (2003). The economic performance of regions, Reg. Studies, 37, 549-578.

Purwaningsih, R., \& Kusuma, P.D. (2015). Analisis Faktor-Faktor Yang Mempengaruhi Kinerja Usaha Kecil Dan Menengah (UKM) Dengan Metode Structural Equation Modeling (Studi kasus UKM berbasis Industri Kreatif Kota Semarang). Prosiding SNST ke-6 Tahun 2015, Fakultas Teknik Universitas Wahid Hasyim Semarang. ISBN 978-602-99334-4-4.

Sampurno. (2010). Manajemen Stratejik: Menciptakan Keunggulan Bersaing yang Berkelanjutan. Yogyakarta: Gadjah Mada University Press.

Setiawan, Y. (2015). Pengaruh Kualitas Pelayanan, Harga dan Brand Image Terhadap Loyalitas Pelanggan di Hotel Syariah Arini Solo. Skripsi Fakultas Ekonomi, Surakarta: Universitas Muhhamadyah Surakarta.

Setyowati, N.W. (2015). Pengaruh Lingkungan Eksternal Dan Lingkungan Internal Terhadap Keunggulan Bersaing Pada Industri Kecil Dan Menengah Di Bandung, Jawa Barat. E S E N S I Jurnal Bisnis dan Manajemen, $5(1)$.

Sriyana, J. (2010). Strategi Pengembangan Usaha Kecil Dan Menengah (UKM): Studi kasus di Kabupaten Bantul, Simposium nasional 2010: Menuju Purworejo Dinamis dan Kreatif.

Stevanus, V.N., Rofiaty, \& Aisjah, S. (2016). Faktor Lingkungan Usaha Dan Strategi diferensiasi Terhadap Keunggulan Bersaing Dan Kinerja Usaha (Studi Pada UMKM di Kota Malang). Media Mahardhika, 15(1), 3137.

Sugiyono. (2014). Metode Penelitian Kuantitatif, Kualitatif, dan Kombinasi (Mixed Methods). Bandung : Alfabeta

Tambunan, T. (2009). UMKM Di Indonesia. Bogor: Penerbit Ghalia Indonesia

Widarti. (2017). Kembangkan UMKM, Pemkot Surabaya Siapkan Rp 11 Milyar. http://kabar24.bisnis.com/read/20170306/78/634438/kembangkan-umkm-pemkot-surabaya-siapkan-rp11miliar, (diakses pada 18 Maret 2018)

Wuisang, J. (2013). Analisis Lingkungan Internal Dan Eksternal Terhadap Kinerja Pada Industri Kecil Kerajinan Keramikdesa Pulutandi Kabupaten Minahasa. Prosiding Pluralisme Dalam Ekonomi Dan Pendidikan, ISSN 2407-4268.

Wulandari, A. (2009). Pengaruh Pengaruh Lingkungan Eksternal Dan Lingkungan Internal Terhadap Orientasi Wirausaha Dalam Upaya Meningkatkan Kinerja Perusahaan. Jurnal Pengembangan Wiraswasta, 11(2).

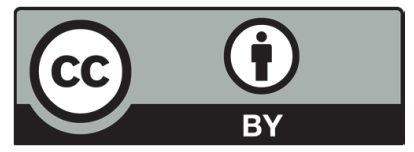

(C) 2019 by the authors; licensee Growing Science, Canada. This is an open access article distributed under the terms and conditions of the Creative Commons Attribution (CCBY) license (http://creativecommons.org/licenses/by/4.0/). 